\title{
Microsatellite Organization in the B Chromosome and A Chromosome Complement in Astyanax (Characiformes, Characidae) Species
}

\author{
Diovani Piscor Patricia P. Parise-Maltempi \\ Instituto de Biociências, Departamento de Biologia, Laboratório de Citogenética, Universidade Estadual Paulista \\ 'Júlio de Mesquita Filho' (UNESP), Rio Claro, Brazil
}

\section{Key Words}

Astyanax schubarti $\cdot$ Chromosome evolution .

Heterochromatin · Mexican blind cavefish · Repetitive DNA

\begin{abstract}
The organization of microsatellites in B and sex chromosomes has been linked to chromosomal evolution in a number of animal groups. Here, the chromosomal organizations of $(\mathrm{CA})_{15},(\mathrm{GA})_{15},(\mathrm{CG})_{15},(\mathrm{GACA})_{4}$, and (GATA $)_{8}$ microsatellites were examined in several Astyanax species with different diploid numbers: Astyanax mexicanus $(2 \mathrm{n}=50+1 \mathrm{~B}$ chromosome), A. altiparanae $(2 n=50)$, A. marionae $(2 n=48)$, A. fasciatus $(2 n=46)$, and $A$. schubarti $(2 n=36)$. The $(C A)_{15}$ and $(\mathrm{GA})_{15}$ microsatellites were dispersed across the chromosomes of $A$. altiparanae and A. fasciatus but were also observed as clusters (CA and GA for A. altiparanae, and CA for A. fasciatus). In A. marionae and A. schubarti, the (CA $)_{15}$ and $(\mathrm{GA})_{15}$ microsatellites were dispersed but were also observed as clustered signals and coincident with heterochromatic regions. In all 4 of these species, the (CG) ${ }_{15}$ and $(\mathrm{GACA})_{4}$ microsatellites were dispersed across chromosomes, and the $(\mathrm{GATA})_{8}$ microsatellite was co-localized with $5 \mathrm{~S}$ rDNA. In $A$. mexicanus, the $(\mathrm{CA})_{15},(\mathrm{GA})_{15},(\mathrm{CG})_{15},(\mathrm{GATA})_{8}$, and $(\mathrm{GACA})_{4}$ microsatellites were weakly detected and dispersed across the chromosomes of the A complement. On the B chromosome, signals for the different microsatellites were weak,
\end{abstract}

strong, absent, weak, and absent, respectively. The distribution of microsatellites and the locational relationship between microsatellites and 5S rDNA are discussed, and a possible evolutionary pathway is proposed for microsatellites in Astyanax.

(c) 2016 S. Karger AG, Basel

Microsatellites are excellent markers for the use in studies of sex and B chromosomes [Pokorná et al., 2011; Milani and Cabral-de-Mello, 2014; Palacios-Gimenez and Cabral-de-Mello, 2015]. For example, abundant accumulation of microsatellites was detected in the W chromosome of the lacertid Eremias velox [Pokorná et al., 2011], and the authors suggested that accumulation of microsatellites in E. velox and other eukaryotic organisms might play an important role in sex chromosome dynamics [Pokorná et al., 2011].

Milani and Cabral-de-Mello [2014] found that, while the majority of examined microsatellites were scattered along the entire length of the B chromosome in Abracris flavolineata (grasshopper), conspicuous blocks were apparent and enriched for (GA) 15 and (GAC) 10 microsatellites. This suggested that microsatellites could play an important role in B chromosome evolution. In this context, the Astyanax genus can be regarded as a good model because of the variation in diploid numbers (e.g.

\section{KARGER}

E-Mail karger@karger.com

www.karger.com/cgr
(C) 2016 S. Karger AG, Basel

$1424-8581 / 16 / 1481-0044 \$ 39.50 / 0$ 
Table 1. Microsatellite organization in the chromosomes of the A complement in Astyanax species

\begin{tabular}{|c|c|c|c|c|c|c|c|}
\hline \multirow{2}{*}{$\begin{array}{l}\text { Species } \\
\text { (diploid numbers) }\end{array}$} & \multirow[t]{2}{*}{$\mathrm{N}$} & \multicolumn{5}{|c|}{ Microsatellites } & \multirow[t]{2}{*}{ Localities } \\
\hline & & $(\mathrm{CA})_{15}$ & $(\mathrm{GA})_{15}$ & $(\mathrm{CG})_{15}$ & $(\mathrm{GACA})_{4}$ & GATA/5S & \\
\hline A. altiparanae (50) & 5 & $\mathrm{C}$ & $\mathrm{C}$ & $\mathrm{S}$ & $S$ & $\mathrm{P}$ & SP, Brazil \\
\hline A. fasciatus (46) & 3 & $\mathrm{C}$ & $\mathrm{S}$ & $\mathrm{S}$ & $\mathrm{S}$ & $\mathrm{P}$ & SP, Brazil \\
\hline A. marionae (48) & 6 & $\mathrm{Ccb}$ & $\mathrm{Ccb}$ & $\mathrm{S}$ & $S$ & $\mathrm{P}$ & MT, Brazil \\
\hline A. schubarti (36) & 1 & $\mathrm{Ccb}$ & $\mathrm{Ccb}$ & $\mathrm{S}$ & $S$ & $\mathrm{P}$ & SP, Brazil \\
\hline A. mexicanus (50) & 6 & $\mathrm{~S}$ & S & $\mathrm{S}$ & $\mathrm{S}$ & $\mathrm{Ab}$ & Mexico $^{\mathrm{a}}$ \\
\hline
\end{tabular}

$\mathrm{Ab}=$ Absent but the GATA repeats showed spreading on the chromosomes of $A$. mexicanus; $\mathrm{C}=$ spread and with fluorescence signals clustered; $\mathrm{Ccb}=$ spread and with fluorescence signals clustered and coincident with $\mathrm{C}$ band heterochromatin; $\mathrm{P}$ = present; $\mathrm{S}=$ fluorescence signals spread; SP = São Paulo state; $\mathrm{MT}=$ Mato Grosso state. ${ }^{\mathrm{a}}$ Mexican blind cavefish obtained from an aquarium store in Brazil.

A. schubarti with $2 \mathrm{n}=36$ and A. altiparanae with $2 \mathrm{n}=50)$ and the presence of species possessing B chromosomes [Moreira-Filho et al., 2004].

Recent surveys on chromosomal microsatellite locations showed that organization in sex chromosomes differed between Leporinus and Characidium species [Poltronieri et al., 2014; Scacchetti et al., 2015]. For example, in $\mathrm{W}$ chromosomes of the Leporinus species, microsatellites accumulated primarily in heterochromatic regions of the long arms. However, microsatellite distributions differed between the 4 Leporinus species, despite the 4 species exhibiting similar patterns of heterochromatin distribution. This suggested that the heterochromatinization process is dynamic, free of selection, and subject to distinctive mechanisms after speciation [Poltronieri et al., 2014].

In this study the chromosomal organization of different microsatellite repeats in Astyanax species with different diploid numbers $(2 \mathrm{n}=36,2 \mathrm{n}=46,2 \mathrm{n}=48$, and $2 \mathrm{n}=$ 50) was analyzed, and the microsatellite distribution in the $\mathrm{B}$ chromosome and A complement of A. mexicanus was examined. Possible scenarios for the evolution of microsatellite distribution and chromosomal clustering of GATA repeats and 5S rDNA are discussed.

\section{Materials and Methods}

\section{Specimens and Classical Cytogenetics}

The following animals were collected: A. schubarti and A. altiparanae from the Piracicaba river in São Paulo state, Brazil; $A$. marionae from the Rio Claro stream in Mato Grosso state, Brazil; A. fasciatus from the Ribeirão Claro river in São Paulo state, Brazil; and A. mexicanus (Mexican blind cavefish) from aquarists in Bra- zil (table 1). Mitotic metaphase chromosomes were prepared using the methods described by Foresti et al. [1981]. Heterochromatin was examined using the C-banding technique described by Sumner [1972].

\section{DNA Extraction and Probe Synthesis}

Genomic DNA was extracted from fin samples as described by Sambrook and Russell [2001]. PCR with the following primers was used to amplify the 5S rDNA probe: A ( $5^{\prime}$-TAC GCC CGA TCT CGT CCG ATC- $\left.3^{\prime}\right)$ and B ( $5^{\prime}$-CAG GCT GGT ATG GCC GTA AGC- $3^{\prime}$ ) as described by Pendás et al. [1994] and Martins and Galetti [1999]. The $(\mathrm{CA})_{15},(\mathrm{GA})_{15},(\mathrm{CG})_{15},(\mathrm{GACA})_{4}$, and $(\mathrm{GATA})_{8}$ microsatellites were amplified and labeled with biotin during synthesis as described by Milani and Cabral-de-Mello [2014]. Microsatellites were donated by Prof. Dr. Diogo C. Cabral-de-Mello for use in laboratory experiments.

\section{Fluorescence in situ Hybridization and Fiber-FISH}

FISH experiments were performed according to Pinkel et al. [1986], with modifications as per Cabral-de-Mello et al. [2010]. Fiber-FISH was performed as described by Barros et al. [2011], and slides were used in double-FISH experiments with 5S rDNA and $(\text { GATA })_{8}$ probes. Signals were detected using anti-digoxigeninrhodamine (Roche, Mannheim, Germany) for digoxigenin and avidin Alexa Fluor 488 conjugate (Invitrogen, San Diego, Calif., USA) for biotin. Slides were mounted with Vectashield Mounting Medium (Vector, Burlingame, Calif., USA) containing DAPI (4',6-diamidino-2-phenylindole) for chromosome counterstaining. Chromosome and fluorescence signals were visualized with an Olympus BX51 microscope coupled to a digital camera (Olympus model D71). Images were captured using DP Controller software.

\section{Results}

Diploid numbers of $A$. altiparanae, A. marionae, $A$. fasciatus, and A. mexicanus are given in table 1. In A. mexicanus, one small acrocentric B chromosome was ob- 
Fig. 1. C-banded metaphases of A. altiparanae (A), A. marionae (B), A. fasciatus (C), and $A$. schubarti (D). Bar $=10 \mu \mathrm{m}$.
A

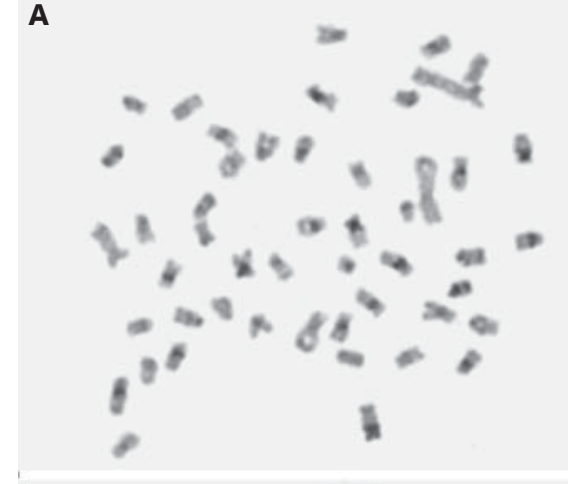

C
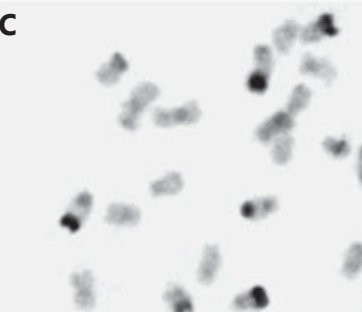

B

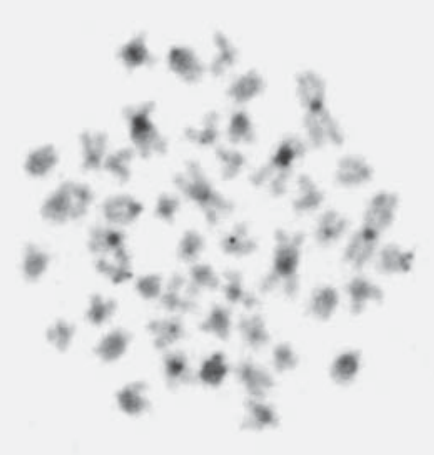

D

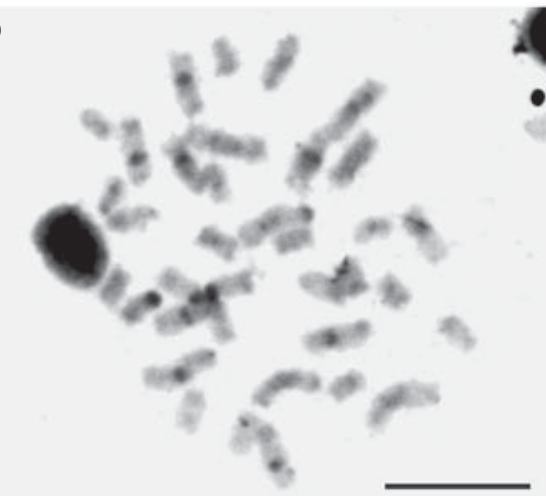

served in all metaphases. Modest blocks of heterochromatin were observed, mainly in the pericentromeric and centromeric chromosomal regions in A. altiparanae (fig. 1A), pericentromeric and centromeric regions in $A$. marionae (fig. 1B), terminal regions in $A$. fasciatus (fig. 1C), and pericentromeric and centromeric regions in A. schubarti (fig. 1D). A. mexicanus chromosomes contained blocks of heterochromatin in the terminal and pericentromeric regions, and the $\mathrm{B}$ chromosome was $\mathrm{C}$ band negative.

Microsatellites were distributed in 4 organizational formats:

1 Dispersed and with blocks of (CA) ${ }_{15}$ and (GA) $)_{15}$ microsatellites, corresponding to $\mathrm{C}$-band heterochromatin in A. marionae and A. schubarti (fig. 2; note that the CA and GA repeats show more evident blocks in $A$. schubarti).

$2(\mathrm{CA})_{15}$ and (GA) ${ }_{15}$ microsatellites were spread across the chromosomes in A. altiparanae and A. fasciatus and were also found in clusters. However, the clusters did not correspond to C-band heterochromatic regions. CA and GA repeats formed clusters in A. altiparanae, but only CA repeats were clustered in A. fasciatus (fig. 2).
$3(\mathrm{CG})_{15}$ and (GACA $)_{4}$ microsatellites were dispersed across the chromosomes in A. altiparanae, A. marionae, A. fasciatus, and A. schubarti (fig. 2).

4 The (GATA $)_{8}$ microsatellite was co-localized with $5 \mathrm{~S}$ rDNA on pair 5 in A. altiparanae, pair 22 in A. marionae, pairs 3 and 22 in $A$. fasciatus, and pairs 3 and 4 in A. schubarti (figs. 3, 4; table 1).

In $A$. mexicanus, the $(\mathrm{CA})_{15},(\mathrm{GA})_{15},(\mathrm{CG})_{15},(\mathrm{GACA})_{4}$, and (GATA) ${ }_{8}$ microsatellites exhibited weak fluorescence signals on the chromosomes of the A complement (fig. 5; table 1). On the $\mathrm{B}$ chromosome, no signal was evident for $(\mathrm{CG})_{15}$ and (GACA) ${ }_{4}$ microsatellites, $(\mathrm{CA})_{15}$ and (GATA) 8 microsatellites produced minimal signals, and $(\mathrm{GA})_{15}$ microsatellite exhibited stronger signals (fig. 5).

\section{Discussion}

Four microsatellite organizations were found in chromosomes of different Astyanax species with a range of diploid numbers: (1) clustered and coincident with Cband heterochromatin, (2) clustered and non-coincident with C-band heterochromatin, (3) dispersed across the chromosomes, and (4) co-localized with 5S rDNA. These 

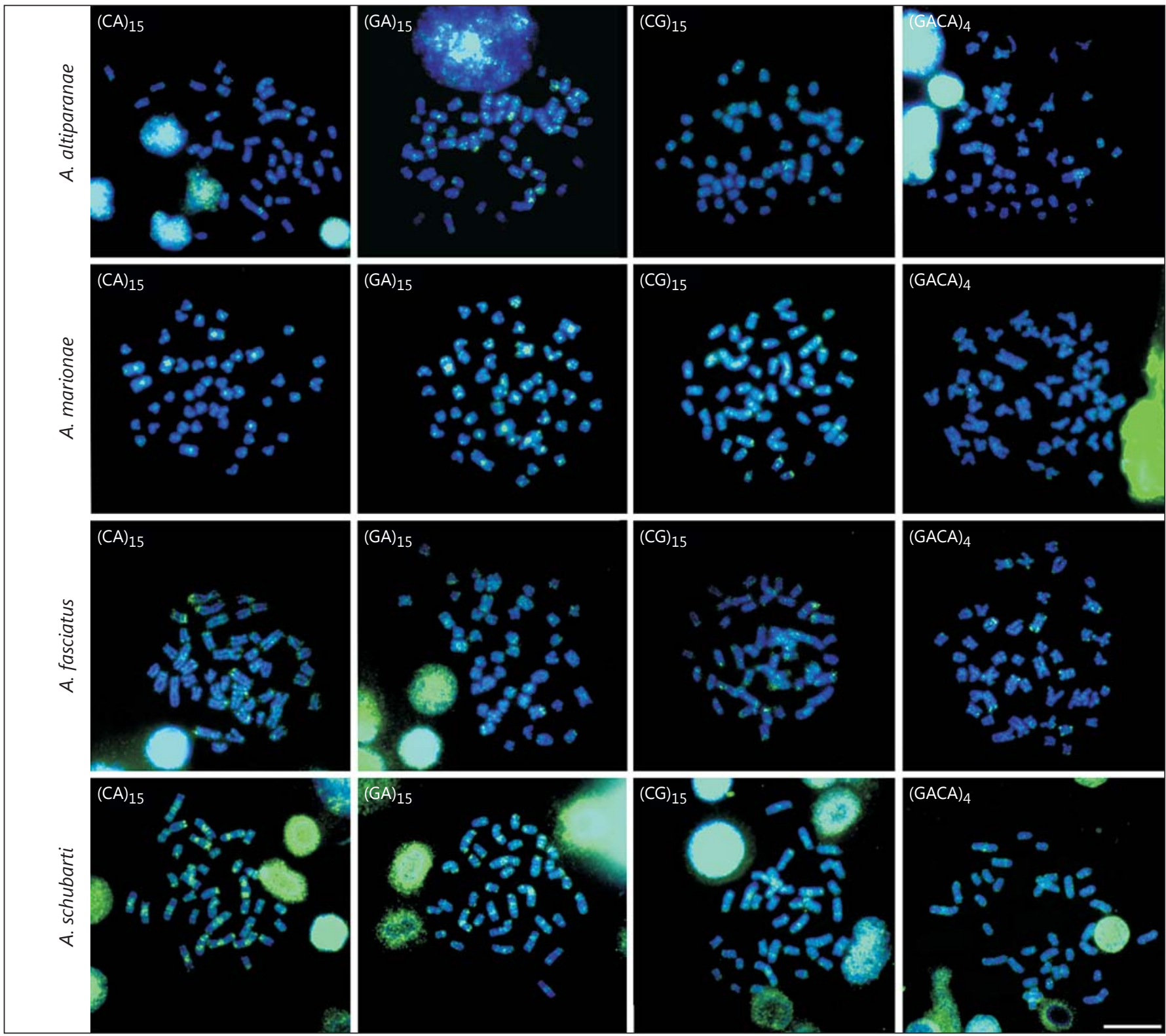

Fig. 2. Microsatellite distribution in chromosomes of Astyanax species. Bar $=10 \mu \mathrm{m}$.

results suggest that there may be 3 evolutionary pathways related to drive and/or genomic organization of microsatellites in Astyanax genomes: (1) the microsatellites can follow a free way to spreading and/or clustering, (2) the heterochromatin can play an important role in the genome organization of the microsatellites, and (3) the colocalization of $5 \mathrm{~S}$ rDNA-GATA can stabilize DNA structures, acting as 'hot spots' for recombination, as discussed by Merlo et al. [2010].

Microsatellite Organization in Astyanax
B chromosomes carrying microsatellite DNA were described previously, for example, in the grasshopper $A$. flavolineata [Milani and Cabral-de-Mello, 2014]. For the authors, microsatellites located on the B chromosome may play an important role in the evolution of these elements. In the present study, A. mexicanus individuals contained 0 or $1 \mathrm{~B}$ chromosome. Thus, the low rate of recombination in the $\mathrm{B}$ chromosome of $A$. mexicanus may facilitate accumulation of microsatellites, as proposed by Charlesworth et al. [2005].

Cytogenet Genome Res 2016;148:44-51 47 
Fig. 3. Chromosomal location of $5 \mathrm{~S}$ rDNA and GATA repeats in Astyanax species. Arrows indicate fluorescence signals. $\mathrm{Bar}=10$ $\mu \mathrm{m}$.
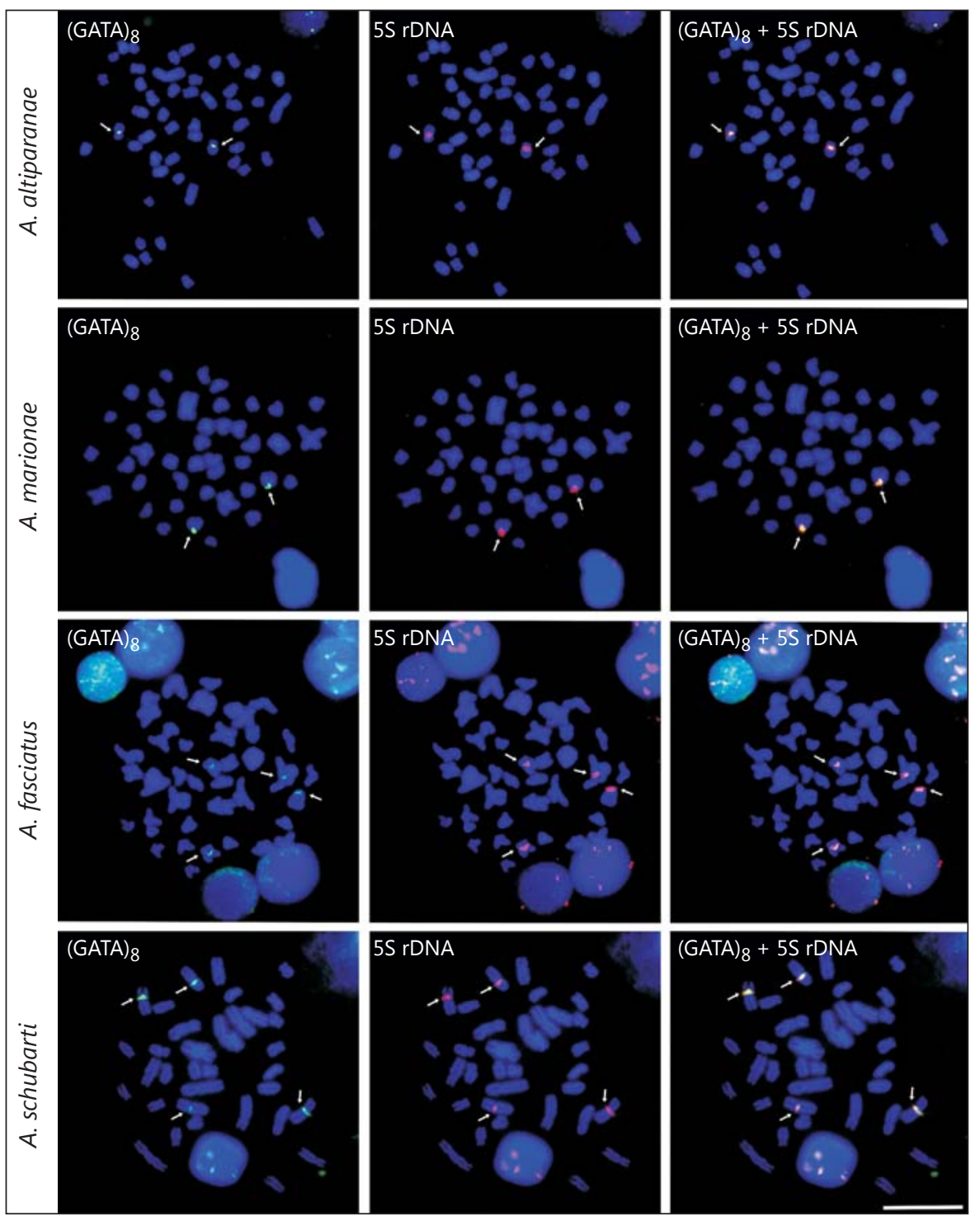

Here, we observed chromosomal co-localization of $5 \mathrm{~S}$ rDNA and the $(\text { GATA })_{8}$ microsatellite. GATA repeats were found on chromosomes of other animal groups, for example, in the grasshopper A. flavolineata [Milani and Cabral-de-Mello, 2014], the fish Halobatrachus didactylus [Merlo et al., 2007], snakes Liasis fuscus, Stegonotus cucullatus, and Notechis scutatus [O'Meally et al., 2010], and lacertids Coleonyx elegans, E. velox [Pokorná et al., 2011], and Aprasia parapulchella [Matsubara et al., 2013]. However, in none of these species were GATA repeats colocalized with ribosomal DNA.

Using 2-color FISH, Úbeda-Manzanaro et al. [2010] examined (GATA $)_{\mathrm{n}}$ and $5 \mathrm{~S}$ rDNA in chromosomes from 4 species of fish of the Batrachoididae family (Amphich- thys cryptocentrus, Batrachoides manglae, Porichthys plectrodon, and Thalassophryne maculosa). GATA repeats were not co-localized with or adjacent to $5 \mathrm{~S}$ rDNA in these species but were dispersed and abundant throughout all chromosomes. According to Úbeda-Manzanaro et al. [2010], GATA sequences cannot be used as chromosomal markers in these fish species. This is in contrast with the results from the present study, which indicate that GATA repeats can act as good chromosomal markers in South American Astyanax species.

Scrutiny of DNA sequences showed that microsatellites could be found within the non-transcribed spacers (NTSs) of 5S rDNA in fish [for examples, see Rocco et al., 2005; Pasolini et al., 2006; Pinhal et al., 2009; Merlo et al., 
Fig. 4. Fiber-FISH of Astyanax chromosomes. The $5 \mathrm{~S}$ rDNA and (GATA) 8 probes are co-localized.

Fig. 5. Microsatellite distribution and constitutive heterochromatin revealed by $\mathrm{C}$ banding in A. mexicanus. Arrows indicate the B chromosome, and insets show fluorescence signals on the $\mathrm{B}$ chromosome. Bars $=10 \mu \mathrm{m}$.
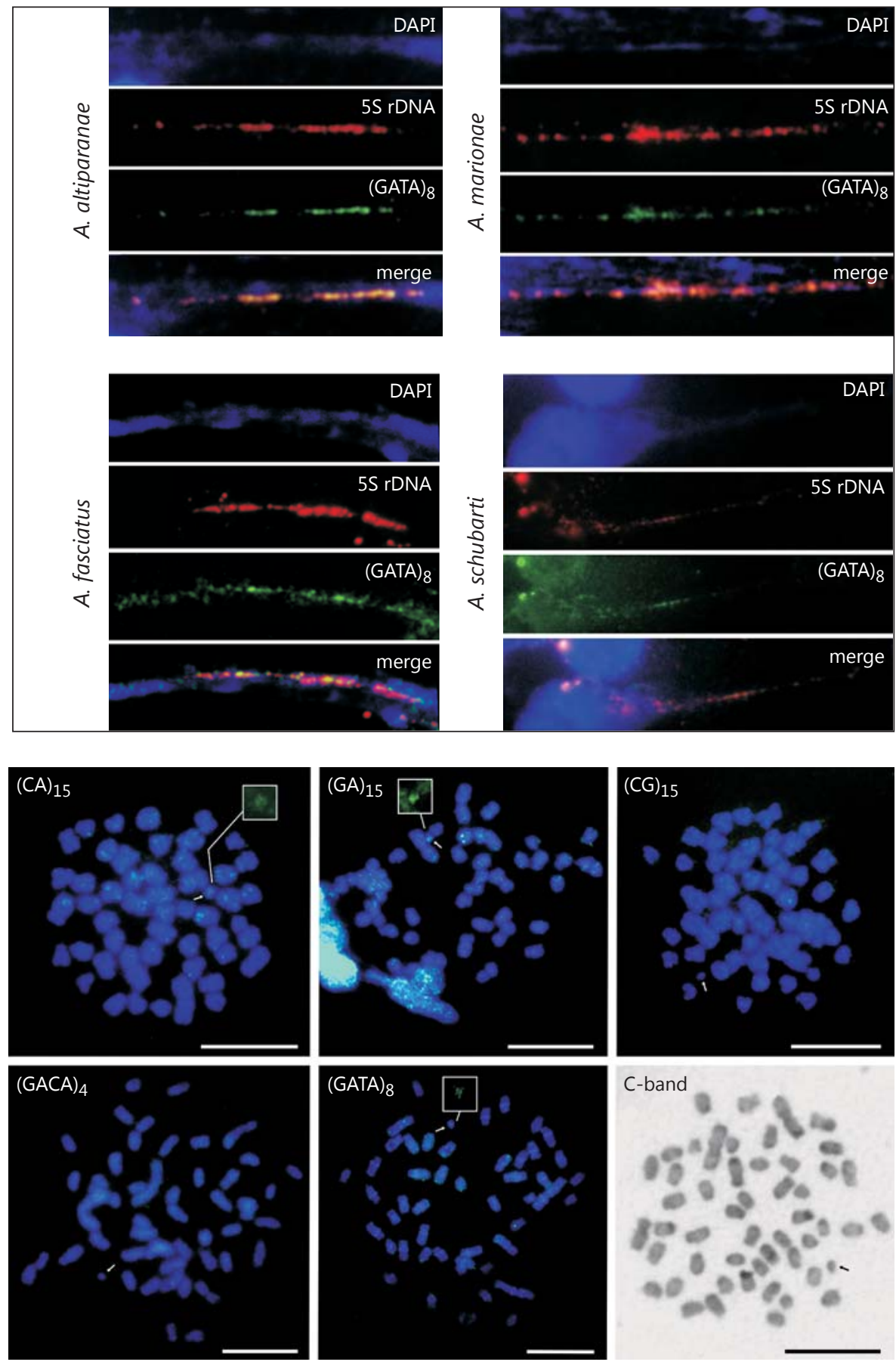

2010]. The microsatellite GTT was found within the NTS from 2 species (Dicentrarchus labrax and D. punctatus) of the Moronidae family [Merlo et al., 2010]. This suggested that the presence of microsatellite repeats favored the maintenance of tandem arrays of multigene families, as proposed by other authors [Liao and Weiner, 1995; Cross and Rebordinos, 2005].
Sequence analysis of $5 \mathrm{~S}$ rDNA in 2 species of Batoidea, Taeniura lymma (Dasyatidae) and Raja montagui (Rajidae), revealed microsatellite repeats in the NTS regions of the $5 \mathrm{~S} \mathrm{rDNA}$, and it was suggested that these repeats might exert an influence on gene regulation [Rocco et al., 2005]. 
The chromosomal co-location of GATA repeats and ribosomal DNA, which was maintained during evolution in different species with different diploid numbers, suggests an evolutionary advantage for the 5S rDNA-GATA combination in Astyanax chromosomes. Furthermore, the absence of $5 \mathrm{~S}$ rDNA-GATA co-location in A. mexicanus indicates that the development of this feature may have occurred relatively recent in the evolutionary history of Astyanax species from South America.

\section{Acknowledgments}

The authors are grateful to Dr. Liano Centofante for suggestions and for provision of cytogenetic preparations, to Dr. Diogo Cavalcanti Cabral de Mello for the microsatellite DNA donated and for the help in the Fiber-FISH technique, and to Octavio M.
Palacios Gimenez and Diogo Milani for their help in the FiberFISH technique. This work was supported by CAPES (Coordenadoria de Aperfeiçoamento de Pessoal de Nível Superior).

\section{Statement of Ethics}

All institutional guidelines for the care and use of laboratory animals were followed. Animals were captured with the permission of the Instituto Chico Mendes de Conservação da Biodiversidade (ICMBio; No. 43497-1) and were used for laboratory experiments approved by the Animal Experimental Ethics Committee from Universidade Estadual Paulista (UNESP; protocol No. 2335).

\section{Disclosure Statement}

The authors have no conflicts of interest to declare.

\section{References}

Barros AV, Sczepanski TS, Cabrero J, Camacho JP, Vicari MR, Artoni RF: Fiber FISH reveals different patterns of high-resolution physical mapping for repetitive DNA in fish. Aquaculture 322:47-50 (2011).

-Cabral-de-Mello DC, Moura RC, Martins C: Chromosomal mapping of repetitive DNAs in the beetle Dichotomius geminatus provides the first evidence for an association of $5 \mathrm{~S}$ rRNA and histone $\mathrm{H} 3$ genes in insects, and repetitive DNA similarity between the $\mathrm{B}$ chromosome and A complement. Heredity 104 393-400 (2010).

-Charlesworth D, Charlesworth B, Marais G: Steps in the evolution of heteromorphic sex chromosomes. Heredity 95:118-128 (2005).

CCross I, Rebordinos L: 5S rDNA and U2 snRNA are linked in the genome of Crassostrea angulata and Crassostrea gigas oysters: does the (CT)n-(GA)n microsatellite stabilize this novel linkage of large tandem arrays? Genome 48:1116-1119 (2005).

-Foresti F, Almeida-Toledo LF, Toledo-Filho SA: Polymorphic nature of nucleolus organizer regions in fishes. Cytogenet Cell Genet 31: 134-141 (1981).

Liao D, Weiner AM: Concerted evolution of the tandemly repeated genes encoding primate U2 small nuclear RNA (the RNU2 locus) does not prevent rapid diversification of the (CT) $\mathrm{n}$-(GA)n microsatellite embedded within the U2 repeat unit. Genomics 30:583-593 (1995).

-Martins C, Galetti PM Jr: Chromosomal localization of 5S rDNA genes in Leporinus fish (Anostomidae, Characiformes). Chromosome Res 7:363-367 (1999).
Matsubara K, Knopp T, Sarre SD, Georges A, Ezaz T: Karyotypic analysis and FISH mapping of microsatellite motifs reveal highly differentiated XX/XY sex chromosomes in the pinktailed worm-lizard (Aprasia parapulchella, Pygopodidae, Squamata). Mol Cytogenet 6:60 (2013).

Merlo A, Cross I, Palazón JL, Sarasquete C, Rebordinos L: Chromosomal mapping of the major and minor ribosomal genes, (GATA) and $(\text { TTAGGG) })_{\mathrm{n}}$ by one-color and doublecolor FISH in the toadfish Halobatrachus didactylus (Teleostei: Batrachoididae). Genetica 131:195-200 (2007).

-Merlo MA, Cross I, Chairi H, Manchado M, Rebordinos L: Analysis of three multigene families as useful tools in species characterization of two closely-related species, Dicentrarchus labrax, Dicentrarchus punctatus and their hybrids. Genes Genet Syst 85:341-349 (2010).

Milani D, Cabral-de-Mello DC: Microsatellite organization in the grasshopper Abracris flavolineata (Orthoptera: Acrididae) revealed by FISH mapping: remarkable spreading in the A and B chromosomes. PLoS One 9:e97956 (2014).

Moreira-Filho O, Galetti PM Jr, Bertollo LAC: B chromosomes in the fish Astyanax scabripinnis (Characidae, Tetragonopterinae): an overview in natural populations. Cytogenet $\mathrm{Ge}$ nome Res 106:230-234 (2004).

O'Meally D, Patel HR, Stiglec R, Sarre SD, Georges A, et al: Non-homologous sex chromosomes of birds and snakes share repetitive sequences. Chromosome Res 18:787-800 (2010).
Palacios-Gimenez OM, Cabral-de-Mello DC: Repetitive DNA chromosomal organization in the cricket Cycloptiloides americanus: a case of the unusual $\mathrm{X}_{1} \mathrm{X}_{2} 0$ sex chromosome system in Orthoptera. Mol Genet Genomics 290: 623-631 (2015).

-Pasolini P, Costagliola D, Rocco L, Tinti F: Molecular organization of $5 \mathrm{~S}$ rDNAs in Rajidae (Chondrichthyes): structural features and evolution of piscine 5S rRNA gene and nontranscribed intergenic spacers. J Mol Evol 62: 564-574 (2006).

-Pendás AM, Morán P, Freije JP, García-Vázquez E: Chromosomal location and nucleotide sequence of two tandem repeats of the Atlantic salmon 5S rDNA. Cytogenet Cell Genet 67: 31-36 (1994).

$\checkmark$ Pinhal D, Araki CS, Godig OBF, Martins C: Molecular organization of $5 \mathrm{~S}$ rDNA in sharks of the genus Rhizoprionodon: insights into the evolutionary dynamics of $5 \mathrm{~S}$ rDNA in vertebrate genomes. Genet Res 91:61-72 (2009).

Pinkel D, Straume T, Gray JW: Cytogenetic analysis using quantitative, high-sensitivity, fluorescence hybridization. Proc Natl Acad Sci USA 83:2934-2938 (1986).

Pokorná M, Kratochvíl L, Kejnovský E: Microsatellite distribution on sex chromosomes at different stages of heteromorphism and heterochromatinization in two lizard species (Squamata: Eublepharidae: Coleonyx elegans and Lacertidae: Eremias velox). BMC Genet 12:90 (2011). 
Poltronieri J, Marquioni V, Bertollo LA, Kejnovsky E, Molina WF, et al: Comparative chromosomal mapping of microsatellites in Leporinus species (Characiformes, Anostomidae): unequal accumulation on the $\mathrm{W}$ chromosomes. Cytogenet Genome Res 142: 40-45 (2014).

Rocco L, Costagliola D, Fiorillo M, Tinti F, Stingo V: Molecular and chromosomal analysis of ribosomal cistrons in two cartilaginous fish, Taeniura lymma and Raja montagui (Chondrichthyes, Batoidea). Genetica 123:245-253 (2005).
Sambrook J, Russell DW: Molecular Cloning: A Laboratory Manual, ed 3 (Cold Spring Harbor Laboratory Press, Cold Spring Harbor 2001).

- Scacchetti PC, Utsunomia R, Pansonato-Alves JC, Vicari MR, Artoni RF, et al: Chromosomal mapping of repetitive DNAs in Characidium (Teleostei, Characiformes): genomic organization and diversification of ZW sex chromosomes. Cytogenet Genome Res 146: 136-143 (2015).
Sumner AT: A simple technique for demonstrating centromeric heterochromatin. Exp Cell Res 75:304-306 (1972).

Úbeda-Manzanaro M, Merlo MA, Palazón JL, Cross I, Sarasquete C, Rebordinos L: Chromosomal mapping of the major and minor ribosomal genes, (GATA) $n$ and U2 snRNA gene by double-colour FISH in species of the Batrachoididae family. Genetica 138:787-794 (2010). 